\title{
Aging, Hormones and Receptors
}

\section{Martin HILL ${ }^{1}$, Zdeněk TŘÍSKALA ${ }^{2}$, Pavla HONCU ${ }^{3}$, Milada KREJČÍI ${ }^{4}$, Jiří KAJZAR ${ }^{4}$, Marie BIČÍKOVÁ ${ }^{1}$, Leona ONDŘEJÍKOVÁ ${ }^{1}$, Dobroslava JANDOVÁ ${ }^{4}$, Ivan STERZL ${ }^{1}$}

${ }^{1}$ Institute of Endocrinology, Prague, Czech Republic, ${ }^{2}$ Ministry of Health of the Czech Republic, Prague, Czech Republic, ${ }^{3}$ Department of Rehabilitation Medicine, Third Faculty of Medicine Charles University in Prague, Czech Republic, ${ }^{4}$ College of Physical Education and Sport Palestra, Prague, Czech Republic

Received May 20, 2020

Accepted June 1, 2020

\begin{abstract}
Summary
Ageing is accompanied by deterioration in physical condition and a number of physiological processes and thus a higher risk of a range of diseases and disorders. In particular, we focused on the changes associated with aging, especially the role of small molecules, their role in physiological and pathophysiological processes and potential treatment options. Our previously published results and data from other authors lead to the conclusion that these unwanted changes are mainly linked to the hypothalamic-pituitary-adrenal axis can be slowed down, stopped, or in some cases even reversed by an appropriate treatment, but especially by a life-management adjustment.
\end{abstract}

\section{Key words}

Aging • Small molecules • Hypothalamic-pituitary-adrenal axis • Life-management $\bullet$ Hormonal receptors

\section{Corresponding author}

M. Hill, Department of Steroids and Proteohormones, Institute of Endocrinology, Národní trída 8, 11694 Prague 1, Czech Republic. E-mail: mhill@endo.cz

\section{Introduction}

Aging (Balachandran et al. 2020, Chen et al. 2019) is associated with an increase in endocrine disorders (Zhavoronkov and Bhullar 2015). On one side, aging is related to changes in hormone secretion mainly in the hypothalamic-pituitary-adrenal axis (HPAA). On the other side there is a decrease in the sensitivity of the HPAA to target hormones and feedback loop mechanisms, as well as decrease in the sensitivity of target tissues to these hormones. Endocrine changes are accompanied by disorders in glucose homeostasis, the loss of muscle and bone mass, and autoimmune and degenerative diseases (Sato and Iemitsu 2018, Watad et al. 2017). This review is focused on changes in hormonal homeostasis associated with aging and agerelated diseases with particular attention to the role of small molecules like steroids, thyroid hormones, neurotransmitters and their receptors.

\section{The hierarchy of endocrine organs/tissues and aging}

\subsection{Hypothalamus}

The anterior hypothalamus produces several releasing hormones such as growth hormone-releasing hormone (GHRH), corticotropin-releasing hormone $(\mathrm{CRH})$, thyroid- releasing hormone (TRH) and gonadotropin-releasing hormone $(\mathrm{GnRH})$ and the inhibiting hormones dopamine and somatostatin. The latter leads to inhibition of the pituitary production of somatotropin and also inhibition of the production of gastrointestinal hormones in the gastro-intestinal tract (Pop et al. 2018).

\subsection{The pituitary gland}

The anterior pituitary is connected to the hypothalamus with blood vessels and upon stimulation 
produces its hormones. After GHRH stimulation growth hormone $(\mathrm{GH})$ is secreted. After stimulation by $\mathrm{CRH}$, adrenocorticotropic hormone (ACTH) is produced, while after TRH stimulation thyrotropin (TSH) is secreted, and after GNRH stimulation both folitropin (FSH) and lutropin $(\mathrm{LH})$ are produced. The production of tropins by the anterior pituitary regulates the activity of the thyroid gland, the adrenal zona fasciculata (ZF), and to a lesser extent also the adrenal zona reticularis (ZR), as well as gonadal (both testicular and ovarian) activity (Melmed 2011, Pignatti et al. 2017). The hypothalamus has direct connections to the posterior pituitary, which secretes vasopressin, also called antidiuretic hormone (ADH) and oxytocin. The latter declines with age. In addition to its positive effects on social behavior, oxytocin is needed for the regeneration and maintenance of the homeostasis of muscle mass. As oxytocin is a US Food and Drug Administration (FDA) approved drug, it potentially may offer a new way to maintain muscle mass during aging (Elabd et al. 2014).

\subsection{Target endocrine organs an aging}

\subsubsection{Thyroid gland}

Levels of free trithyronin ( $\mathrm{fT}_{3}$ ) have a negative correlation with age, however, the TSH activity also declines with age (Strich et al. 2016, Surks et al. 2004). Aside from these changes, research has found an increasing prevalence of autoimmune complications in the thyroid gland, which can influence the levels of thyroid hormones (Bremner et al. 2012, Chaker et al. 2016). Changes to the function of the hypothalamicpituitary-thyroid (HPT) axis with age can also be associated with a range of pathologies, such as cardiovascular diseases (Biondi et al. 2015), dementia (Rieben et al. 2016), and decreased bone mass (Segna et al. 2018). It has been reported that subclinical hypothyroidism, i.e. higher TSH levels correlate with lower mortality in the elderly (Atzmon et al. 2009, Selmer et al. 2014).

\subsubsection{The adrenal medulla}

The adrenal medulla produces the catecholamines adrenalin and noradrenalin. In skeletal muscles, catecholamines induce vasodilation, which is a part of the preparation for motor activity. From the point of view of aging, it is important that catecholamine secretion is stimulated by physical stressors and factors such as hypoglycemia, excessive physical stress, injury, emotional swings resulting from fear, anxiety, anger, rage, aggression as well as pain. Sympathetic activation increases with age in the heart, intestines, and liver at rest. In the elderly, sympathetic nerve responses to stressors are increased, while in contrast secretion of adrenalin from the adrenals is lowered, both at rest and during stress (Esler et al. 2002).

\subsubsection{Adrenal cortex}

The adrenal cortex consists of three zones with specific steroid production, with each zone regulated by a different system. In addition to the production of active androgens in men, the primary source of most steroids in the elderly is the adrenal cortex, though steroid metabolism also occurs in other peripheral organs and tissues and to a small degree in nervous system tissues (Labrie et al. 2017). In elderly females, steroidogenesis in the non-functional ovaries can be disregarded. Estrogen precursors in both elderly males and females are primarily produced in the adrenal gland, while the sources of active estrogens are peripheral tissues, and particularly adipose tissues, which metabolize primary adrenal steroids. However, some testosterone can be produced directly in the adrenal cortex, which in the zona reticularis (ZR) shows a relatively marked activity of the aldoketoreductase ADR1C3 converting androstenedione to testosterone (Nakamura et al. 2009).

\subsubsection{Zona glomerulosa $(Z G)$ and the renin-angiotensin system}

The external zone of the adrenal cortex is the zona glomerulosa ( $\mathrm{ZG}$ ), which is part of the reninangiotensin system. In response to increasing $\mathrm{K}^{+}$levels, renin, or lowered blood flow in the kidneys, the ZG produces the mineralocorticoid aldosterone. $Z G$ expresses enzymes enabling the conversion of cholesterol to 11-deoxycorticosterone (DOC), such as cholesterol desmolase (CYP11A1), 21-hydroxylase (CYP21A1), and 3 $\beta$-hydroxysteroid dehydrogenase type II (HSD3B2), which are also expressed by the zona fasciculata (ZF). HSD3B2 is an enzyme specific to the adrenal gland ( $\mathrm{ZG}$ and $\mathrm{ZF}$ ). Another enzyme specific to the $\mathrm{ZG}$ is aldosterone synthase (CYP11B2). This enzyme converts DOC to 18-hydroxy-corticosterone and then aldosterone, which is the target bioactive steroid. In addition to the physiological production of aldosterone dependent on angiotensin II, low $\mathrm{Na}^{+}$levels and high $\mathrm{K}^{+}$levels can lead clusters of cells in the ZG (aldosterone-producing cell clusters, APCC) to autonomically express CYP11B2, and at the same time increased the autonomic secretion of 
aldosterone, while physiological secretion declines. APCCs are not neoplastic or tumor cells, their activity is not hyperplastic, and they are normally present in the ZG. However, this increased autonomic aldosterone production with age can be associated with an increased risk of cardiovascular disease (Nanba et al. 2018, Nanba et al. 2017).

\subsubsection{Zona fasciculata (ZF)}

The next, lower level of the adrenal cortex, the $\mathrm{ZF}$ is regulated by pituitary ACTH. In addition to the 11ß-hydroxylase enzyme (CYP11B1), steroidogenic enzymes in ZF also include the C17-hydroxylase-C17,20 lyase (CYP17A1), the activity of which is stopped in the first step in ZF, i.e. C17-hydroxylation of 17-deoxysteroids, because of the low expression of a specific hemoprotein for transporting electrons of cytochrome B5 (CYB5). These enzymes (in the sequence) produce pregnenolone, 17-hydroxypregenolone, 17-hydroxyprogesterone, 11-deoxycortisol, and the target product cortisol, which in humans is the key glucocorticoid. ZF express at lower levels the most active isoform of steroid sulfotransferase (SULT2A1) catalyzing the sulfation of pregnenolone and 17-hydroxypregnenolone. A second, lyase step catalyzed by CYP17A1 and the splitting a link between $\mathrm{C} 17$ and $\mathrm{C} 20$ of the steroid is also underway to a limited extent, with androstenedione thus synthesized in ZF (Seccia et al. 2018, Vinson 2016). The age-related alterations in $\mathrm{ZF}$ functioning are described latter in the text (see section 3.1.3.).

\subsubsection{Zona reticularis $(Z R)$}

The innermost zone of the adrenal cortex is the $Z R$. The ZR is present in only some mammals including humans. Cytochrome B5 (CYB5) is expressed widely in the $\mathrm{ZR}$, and for this reason the lyase step of CYP17A1 is preferred over $\mathrm{C} 17$ hydroxylase. Further, as a result of CYB5 activity, the expression of HSD3B2 is blocked in the ZR, while the expressions of SULT2A1 and AKR1C3 are increased. Thus dehydroepiandrosterone (DHEA) sulfate (DHEAS) is the main product of the ZR. Meanwhile, the DHEAS is the most biologically active non-genomic-acting steroid in human (Seccia et al. 2018, Vinson 2016). The activity of the ZR is influenced by $\mathrm{ACTH}$, but the reaction of steroidogenic enzymes in the $\mathrm{ZR}$ to ACTH is weaker than in ZF. Moreover, CRH directly stimulates ZR activity (Ibanez et al. 1999a, Ibanez et al. 1999b, Sirianni et al. 2005). Aging in both sexes is associated with a decline in adrenal androgens, a decline in CYB5 activity, reduction in the lyase step of CYP17A1 and reduced ZR mass. The decline in adrenal androgen production negatively influences bone density and libido, as well as the immune system and perception ability (Dharia et al. 2005).

The skeletal musculature has the ability to synthesize and metabolize sex hormones from DHEA (Sato and Iemitsu 2018). Maximal levels of DHEA are reached between the ages of 20-30 years, and then significantly decline until old age by 75 to $90 \%$ causing similar trends for androgens and estrogens in peripheral target tissues. This could be associated with pathogenic diseases related to age such as obesity and type 2 diabetes (DM2). The expression of steroidogenic enzymes such as HSD3B2 and some isoforms of HSD17B and SRD5A show declines with age from levels found in younger men, as do the levels of both serum and musculature steroids such as DHEA, free testosterone, and $5 \alpha$-dihydrotestosterone, which show a $30-50 \%$ decline (Sato and Iemitsu 2018). In addition to DHEAS and other adrenal androgens (Sulcova et al. 1997, Vermeulen 1995), pregnenolone, 17-hydroxypregnenolone (Hill et al. 1999), and especially their sulfates (Havlikova et al. 2002) largely declines with advancing age. Moreover, the patients with Alzheimer's disease (AD) compared to corresponding controls show reduced levels of the most important human sulfotransferase SULT2A1, primarily expressed in ZR (Vankova et al. 2015).

From the results of many studies it can be generally concluded that there is a positive correlation between adrenal androgens (DHEA/DHEAS) on one side and muscle strength, quality of bone microarchitecture and lower number of falls on the other side in both genders. However, these results differ in some of the details (Carrer et al. 2019, Kong et al. 2019, O'Donnell et al. 2006, Ohlsson et al. 2018). Some authors reported that there was a linear relationship between performance results and hormone levels up to a certain threshold concentration of hormone levels, after which the correlation weakened and then disappeared or even slightly reversed in trend polarity (O'Donnell et al. 2006).

The decline in DHEA levels is connected with lower physical vitality in women. An early decline might be associated with lower vitality and can predict worsening health as one ages. Female patients with lower-than-average DHEAS and DHEA levels for their age show a higher incidence of chronic diseases and higher levels of chronic pain and higher sensitivity to 
pain. In addition, lower DHEAS and DHEA levels positively correlate with poorer results on tests of physical condition and physical functioning in middle ages (Rendina et al. 2017).

Physical activity is a proven effective method for preventing a worsening of health due to aging. A 12-day exercise program in older men increased muscular levels of DHEA, free testosterone and 5 $\alpha$-dihydrotestosterone, and led to increased expression of steroidogenic enzymes such as HSD3B2, some isomers of HSD17B, and SRD5A (Sato et al. 2014). After the 12-week yoga training, there was a significant increase in GH and DHEAS levels in both sexes compared to before the experiment, while in the control group there were no significant changes found (Chatterjee and Mondal 2014). A combination of DHEA and physical training increases both the levels of circulating and muscle steroid sex hormones, and decreases insulin resistance while simultaneously increasing muscle mass and strength (Sato and Iemitsu 2018).

A U-shaped relationship has been found between mortality and DHEAS. Women with higher DHEAS levels had a tendency for higher mortality from carcinomas, while women with lower DHEAS had a tendency for mortality from cardiovascular disease (Cappola et al. 2006).

\subsubsection{Testes}

In the interstitial tissue surrounding the seminal tubules, Leydig cells are present that produce testosterone. Testicle size in older men positively correlates with serum levels of the testicular hormone inhibin B, secreted by the Sertoli cells, and testosterone (Seevagan et al. 2019). The testes have two main functions - spermatogenesis, and steroidogenesis that are not completely independent. Under normal circumstances, the hypothalamus secretes GnRH, which stimulates the secretion of FSH and LH in the pituitary. $\mathrm{LH}$ binds to LH receptors in Leydig cells, stimulating the biosynthesis of testosterone. FSH binds to FSH receptors on Sertoli cells, with a consequent sperm production. Both these functions are influenced by age, which leads to changes in hormone levels including lower androgen levels. However, this does not necessarily lead to the complete halt in their production capacity, as in the female sex organs after menopause. In addition to the decline in testicular androgens, the production of inhibin B and the number of Sertoli cells declines in men (Santiago et al. 2019). Levels of testosterone in older men are positively correlated with muscle, quality of bone microarchitecture, strength and physical condition, independently of muscle mass (Auyeung et al. 2011, O'Donnell et al. 2006).

\subsubsection{Metabolic hormones, proinflammatory cytokines, and skeletal musculature}

Sarcopenia is an age-related loss of skeletal musculature that is characterized by worsening amounts and quality of muscle mass. This leads to a gradual slowing of movement, declines in musculature, and increased risk of injury from falls. In addition to physical exercise with amino acid supplements, inhibition of myostatin (a proteohormone produced in muscle cells that inhibits their growth) seems to be a promising strategy for limiting sarcopenia (Sakuma and Yamaguchi 2012). The aging process is associated with a large decline in the secretion of GH (Sato and Iemitsu 2018). The somatotropic effects of $\mathrm{GH}$ are mediated by the production of insulin like peptides and their interaction with plasma membrane receptors of the cells (possibly via autocrine or paracrine activity). Most of the activity of circulating somatomedins in humans can be accredited to insulin-like growth factors I and II (IGF-I and IGF-II). Levels of circulating IGFs are influenced by GH, though IGF-I is more sensitive. In humans, levels of circulating IGF-I reach a maximum in adolescence and then decline with age. These lower IGF-I levels are associated with the decreased secretion of $\mathrm{GH}$ that accompanies aging (Hammerman 1987). Despite the fact that IGF-I is an effective regulator of muscle mass, its therapeutic use has not been positive. In contrast, ghrelin treatment can lessen the age-related atrophy in muscle mass caused by the decline in GH with age (Sakuma and Yamaguchi 2012). Another hormone, glucagon-like peptide-1 (GLP-1) likely acts protectively, since agonists for its receptor (GLP-1R) effectively reduce muscle atrophy, and in laboratory rodents supports myogenic factors. In seniors, the levels of the proinflammatory cytokines TWEAK and TNF- $\alpha$ positively correlate with the risk of sarcopenia on the one hand, but metabolic hormones such as insulin, IGF-I and adiponectin are associated with lower risks of sarcopenia on the other hand (Li et al. 2019).

\section{Hormonal receptors and aging}

\subsection{Nuclear receptors (NRs)}

\subsubsection{Progesterone receptors (PRs)}

Progesterone is in sub-nanomolar levels in men, and postmenopausal women (Bae et al. 2019). 
Nevertheless, progestogens and some of their reduced metabolites are neuroprotective molecules that act in both the central (C) and peripheral nervous systems (PNS) (see review Hill et al. 2011). They exhibit antiinflammatory effects, support the myelination and re-myelination of Schwann cells in the PNS, as well as, regulate neurogenesis, protect mitochondrial cells, and influence mood, memory, and recognition. Because of their low polarity, progestogens easily cross the bloodbrain barrier to the CNS but are also active in the PNS (Jure et al. 2019, Schumacher et al. 2014).

\subsubsection{Mineralocorticoid receptors (MRs)}

Ligands of MRs regulate blood pressure, influencing the balance between electrolytes and water in the kidney. The primary mineralocorticoid is aldosterone, but affinity to nuclear MRs is also shown by its precursors DOC, corticosterone, and the primary human glucocorticoid cortisol. Nuclear MRs are also expressed in extra adrenal tissues, such as the heart, vascular tissue, and adipose tissue (Gorini et al. 2019). Aging leads to the activation of nuclear MRs, which acts profibrotically leading to vasoconstriction, lowers arterial elasticity, and subsequently to higher blood pressure (Omar et al. 2012).

\subsubsection{Nuclear glucocorticoid receptors (GRS) and transmembrane mineralocorticoid receptors (tMRs)}

These bioactive steroids are immunosuppressive and anti-inflammatory mediators. In addition to binding to GRs, in the CNS glucocorticoids bind to transmembrane mineralocorticoid receptors (tMRs) (Ruhs et al. 2017). While binding to nuclear GRs has a slower effect, binding to tMRs induces a rapid response (de Kloet et al. 2018). In addition, the affinity of the glucocorticoids cortisol and corticosterone to tMRs is about an order of magnitude higher than to GRs, and levels of the classic mineralocorticoid aldosterone are about 1-2 orders lower than endogenous glucocorticoids depending on the diurnal rhythm. Finally, like adrenal androgens the secretion of aldosterone and renin depends on age (de Kloet et al. 2018). The tMRs are expressed in limbic neurons of the hippocampus (HC), the lateral septum, and amygdalla, and bind, in addition to cortisol and corticosterone, several other steroids such as aldosterone, its precursor DOC, and progesterone (de Kloet et al. 2018).

While the response mediated by transmembrane GRs is targeted to emotion and immediate decision making, the slower response mediated by MRs is targeted to contextualization, rationalization, and storing stressful situation into memory. Antagonists of GR therefore impair memory, while antagonists of tMRs slow the storage of situation in memory (de Kloet et al. 2018). The $\mathrm{HC}$ and prefrontal cortex first inhibit the activity of the stress response, while the amygdala activates them (Yiallouris et al. 2019). The tMRs also direct the tonic effects of glucocorticoids in the brain at a basal levels, while activation of GRs inhibit further increases in the activity of the stress response (de Kloet et al. 2018, Yiallouris et al. 2019). The tMRs mediate the threshold of HPAA reactivity during stress that is considered a "healthy" state (de Kloet et al. 2018).

The balance between phases under the control of tMRs and nuclear GRs is related in a U-shaped curve with levels of glucocorticoids. However, in regions with a predominant expression of tMRs this relationship is linear (de Kloet et al. 2018). An imbalance between phases of the stress response mediated by tMRs and nuclear GRs leads to damage to the stress response and a predisposition to a range of pathologies (de Kloet et al. 2018). In general, aging is associated with a weakening of feedback between cortisol secretion because of impaired HPAA sensitivity (Yiallouris et al. 2019). As a result, higher levels of corticoids and a flatter diurnal profile are associated with lower abilities of recognition, anxiety, depression, dementia, and neurodegenerative disorders (Yiallouris et al. 2019).

As opposed to the clear decline in the production of adrenal androgens, average corticoid levels have rather the opposite trend (Yiallouris et al. 2019). A flatter circadian profile of corticoids with higher levels and night and lower in the morning has been described in a number of studies (de Kloet et al. 2018, Roelfsema et al. 2017, Yiallouris et al. 2019). In addition, the enzyme 11ß-hydroxysteroid dehydrogenase type 1 (HSD11B1), which converts non-active 11-oxy-corticoids to their bioactive $11 \beta$-hydroxylated forms, is expressed in CNS tissues and its activity increases with age, while lower average glucocorticoid levels are associated with longevity (Yiallouris et al. 2019).

\subsubsection{Estrogen receptors (ERs)}

Estrogens play a central role in regulating lipid metabolism in the CNS, as weakened estrogen receptors $\alpha(E R \alpha)$ function leads to increased food intake. Activation of ER $\beta$ has an anti-lipogenic effect, and further lowers insulin resistance and glucose intolerance. ERs also influence the retention of glucocorticoids in 
skeletal muscle. In addition, estrogens help increase the production of HDL cholesterol and triglycerides, and in contrast helps lower the production of LDL cholesterol in postmenopausal women. Estrogens are known for their rapid regulatory activity in pancreatic $\beta$-cells through the depolarization of cellular membranes with the subsequent flow of calcium ions into the cell and activation of insulin secretion. In addition, estrogens protect $\beta$-cells from apoptosis. An absence of ER $\alpha$ leads to a $\beta$-cell dysfunction associated with hyperinsulinemia. Therefore, the long-term estrogen therapy has anti-diabetic effects (Jia et al. 2015).

\subsubsection{Vitamin D receptor (VDRs)}

The ligand for VDRs is the active form of vitamin $\mathrm{D}$ calcitriol (1,25-dihydroxycholecalciferol). The most common disorders associated with aging and VDR/calcitriol deficiency are sarcopenia (a degenerative loss of skeletal muscle mass), and osteoporosis (Garcia et al. 2019, Scimeca et al. 2018).

\subsubsection{Peroxisome proliferator-activated receptors (PPARs)}

PPARs are nuclear transcription factors that play a key role in energy homeostasis and in the pathophysiology of many age-related disorders, such as increased oxidative stress, inflammatory reactions, and insulin resistance, and PPAR agonists can be used in the treatment of these disorders. Energy restriction, the most effective intervention in offsetting the effects of aging, leads to declines in oxidative stress and a lessening in inflammatory reaction, reduced adipose tissue and fasting glycemia levels, and thus prolonging life (Erol 2007).

\subsubsection{Thyroid receptors (TRs)}

The key ligand for TRs is $T_{3}$. TRs play a key role in the metabolism of cholesterol and saccharides and the regulation of pulse. $\mathrm{T}_{3}$ stimulates energy output through thermogenesis in brown adipose tissue, leading to a loss of body weight. $\mathrm{T}_{3}$ also stimulates increased lipolysis, lowers cholesterol levels, increases the production and induces declines in insulin secretion and increased gluconeogenesis (Mullur et al. 2014). Levels of thyrotropin that stimulate the production of $T_{3}$ in the thyroid increase with age, while levels of the $T_{3}$ precursor thyroxine $\left(\mathrm{T}_{4}\right)$ remain unchanged (Bremner et al. 2012). Several authors have proposed that slightly reduced thyroid gland activity with aging might be optimal for increasing longevity (Bowers et al. 2013).

\subsubsection{Transcription factors for protein activation connected} to xenobiotic detoxification

Pregnane $\mathrm{X}$ receptors (PXRs), constitutive androstane receptors (CARs), liver X receptors (LXRs) and farnesoid receptors (FXRs) act as transcription factors for the activation of proteins connected to xenobiotic and endobiotic detoxification and their eliminations from the organism in coordination with other factors, molecules (e.g. PPAR) and enzymes such as sulfotransferases and some P450 cytochromes (CYPs) (Kodama and Negishi 2013). In addition, these receptors are targets for influence by androgen activities (Zhang et al. 2010). The main organs that play a role in detoxification and excretion of xeno and endobiotics are the liver, kidneys and GI tract tissues. From a functional perspective, VDRs can be included in this group of receptors (Kodama and Negishi 2013).

In addition to sulfotransferases, the main target of PXR activation is the gene for the enzyme CYP3A4, which catalyzes the conversion of 16-deoxy steroids to immunoprotective 16 $\alpha$-hydroxy analogs and further converts 7-deoxy androgens to their immunoprotective 7 $\beta$-hydroxy analogs (Sterzl et al. 2017). CYP3A4 expression in seniors of both sexes markedly declines with increasing age, as does PXR expression particularly in men (Uno et al. 2014). Ligands for PXR include a wide variety of hydrophobic xenobiotics and endobiotics, the levels of which typically range in $\mu \mathrm{mol} / 1$, and endobiotics such as steroids and bile acids also activate PXRs acids (Kliewer et al. 2002). Co-activators of PXRs include for instance PPAR $\gamma$. Activation of PXRs is associated with a range of pathologies, including diabetes, and osteomalacia (Kodama and Negishi 2013). On the other hand, PXR activation can inhibit some inflammatory processes (Garg et al. 2016, Kodama and Negishi 2013). CARs, with several androstane steroids as ligands, and also LXR $\beta$ influence the expression of sulfotransferases (Kodama and Negishi 2013).

\subsection{Transmembrane receptors (metabotropic, G-protein coupled)}

\subsection{1. ע-aminobutyric acid receptors type $B\left(G A B A_{B} \underline{R} \underline{R}\right.$}

$\mathrm{GABA}_{\mathrm{B}} \mathrm{Rs}$ are metabotropic transmembrane receptors coupled with $G_{i / o}$ protein. $G_{A B A} R s$ regulate nerve activity by opening potassium channels or inhibiting calcium channels through the $G_{i / o}$ protein signaling cascade. Successful tests have been done using $\mathrm{GABA}_{\mathrm{B}} \mathrm{R}$ antagonists to reduce cognitive deficits in patients with Alzheimer's disease (AD) (Li et al. 2016). 


\subsubsection{Dopamine D1 receptors}

Dopamine influences skeletal muscle tone through the activation of type D1 receptors on somatic motoneurons (Schwarz and Peever 2011). Aging negatively effects dopamine transporters and receptors, but not on production of dopamine itself (Karrer et al. 2017).

\subsection{Ionotropic receptors}

\subsubsection{Nicotinic acetylcholine receptors ( $n A C h R s)$}

The nAChR ligands are the excitatory endogenous neurotransmitter acetylcholine. nAChRs are expressed in the CNS and PNS, and are the primary receptors for muscle contractions, with changes to their function associated with pathogenic neurodegenerative diseases (Kalamida et al. 2007). High levels of acetylcholine and choline acetyltransferases occur in the nucleus accumbens (NAc). The cholinergic activity in the NAc is connected to ceasing food intake and with satiation (Salgado and Kaplitt 2015). Thalamic nAChR plays a key role in coordinating attention and speech. The affinity of $\mathrm{nAChR}$ to its agonists and its abundance decline with age, and the composition of its subunits changes as well (Sottile et al. 2017). Together, agonists of nAChR slow the development of neurodegenerative diseases (Picciotto and Zoli 2002). Endogenous low-molecular-weight compounds inhibiting nAChR include triiodothyronine, progesterone, PregS, and other less-potent steroids such as estradiol and corticosterone (Ke and Lukas 1996).

\subsubsection{Glycine receptor $(G l y R)$}

GlyRs are neuroinhibitory chloride channels influencing the rapid transduction of nerve signals in the spine and brain stem (Schaefer et al. 2018). Glycine receptors also play an important role in physiological hearing and speech (Caspary et al. 2008) and in pathophysiological disorders of the same (Richardson et al. 2012, Wang et al. 2009). With aging there is a decline in the total number of GlyR binding sites and changes to the expression of their subunits in the dorsal cochlear nucleus, leading to worsening hearing (Wang et al. 2009). Some endogenous steroids such as allopregnanolone or pregnenolone positively modulate GlyR (Jiang et al. 2006, Maksay et al. 2001), while others are negative modulators (PregS, DHEAS, androsterone sulfate, epiandrosterone sulfate, progesterone, pregnenolone) (Jiang et al. 2006, Maksay et al. 2001, Weir et al. 2004, Wu et al. 1990).
3.3.3. y-aminobutyric acid receptors types $A$ and $C$

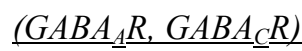

In the $\mathrm{CNS}, \mathrm{GABA}_{\mathrm{A}} \mathrm{R}$ ensures the rapid inhibition of open ion channels for the flow of chloride ions into the cell. Subunits of $\mathrm{GABA}_{\mathrm{A}} \mathrm{R}$ have relatively different function. For instance, the $\alpha_{1}$ subunit allows the sedative effects of diazepam, the $\alpha_{2}$ subunit mediates anxiolytic effects, while the $\alpha_{5}$ subunit is associated with worsening recognition and memory. In $\mathrm{AD}$, hyperexcitation is considered one of the toxic factors leading to neuron death. For this reason, $\mathrm{GABA}_{\mathrm{A}} \mathrm{R}$ agonists have been successfully tested in mitigating the AD manifestation (Li et al. 2016).

Similarly to dopamine, antagonists to $\mathrm{GABA}_{\mathrm{A}} \mathrm{R}$ increase mobility (Salgado and Kaplitt 2015). As the $\gamma$-aminobutyric acid (GABA) is also a key inhibitory neurotransmitter in the primary motor cortex, the lowering of extrasynaptic $\mathrm{GABA}_{\mathrm{A}} \mathrm{R}$ activity with age very likely contributes to dysfunctions of motor abilities (Mooney et al. 2017). Furthermore, increases in dopamine and GABA levels in rats arising from the activation of glutamate receptors in the NAc and basal ganglia decline as the animals age (Segovia and Mora 2005). In addition to motor activity, NAc is responsible for motivation and emotional processes. It is interesting that giving GABA in small doses increases mobility, but at higher doses induces hypoactivity (Mora et al. 2008, Salgado and Kaplitt 2015).

Some unconjugated endogenous neuroactive steroids and neurosteroids such as $5 \alpha / \beta$-reduced pregnanes and androstanes with hydroxyl at position $3 \alpha$ can be positive GABAergic modulators, while other steroids can be their antagonists (PregS, 20 $\alpha$-dihydroPregS, isopregnanolone sulfate, DHEAS, androsterone sulfate) (Belelli et al. 1996, Li et al. 2007, Lundgren et al. 2003, Park-Chung et al. 1999, Rahman et al. 2006, Sullivan and Moenter 2003, Wang et al. 2002).

\subsubsection{Glutamate receptor}

\subsubsection{AMPA receptor (AMPAR)}

AMPARs (2-amino-3-3-hydroxy-5-methylisoxazol-4-yl propanoic acid receptors) are glutamate receptors with the fastest excitatory transmission in the $\mathrm{CNS}$ and they play a key role in the regulation of brain function including learning and memory. For this reason, one of the first biological signs of AD is reduced synaptic AMPARs and dysfunctions of synaptic plasticity. NMDAR-dependent plasticity is the basis for processing information, learning, and memory, which are slightly 
worsened in seniors, though normally with non-harmful outcomes. This natural cognitive decline is not likely associated with significant nerve loss, but rather with the reorganization of synaptic structures. In general, longterm potentiation of AMPARs in older individuals is less robust and requires a stronger initial stimulus. On the other hand, the long-term depression is facilitated (Jurado 2017). Endogenous steroids acting as negative modulators of AMPARs include primarily PregS and DHEAS (declining with advancing age) (Havlikova et al. 2002, Sulcova et al. 1997), and further sulfates of allopregnanolone and pregnanolone (see reviews Jurado 2017, Ratner et al. 2019).

\subsubsection{2. $N$-methyl-D-aspartate receptor (NMDAR)}

Like the AMPARs NMDARs play a key role in learning and functioning of spatial memory. Several studies have shown a decline in NMDAR functionality and a lowered expression of subunits in the nervous system with increasing age (Clayton et al. 2002, Kumar 2015, Newcomer et al. 2000). Some endogenous steroids such as PregS, 17-hydroxy-PregS, DHEAS and $20 \alpha$-dihydro-PregS, can be positive modulators of NMDARs. Others, such as pregnanolone sulfate, act as negative modulators (see review Vyklicky et al. 2014).

\subsubsection{Inward rectifier potassium channels $\left(K_{i r}\right)$}

\subsubsection{ATP-sensitive $K_{\text {ATP }}$ potassium channels}

$\mathrm{K}_{\mathrm{ATP}}$ channels play an important role in the pathophysiology of DM2 in association with L-type calcium channels (Fridlyand et al. 2013, Jia et al. 2015). Similarly, estrogens regulate $\mathrm{K}_{\mathrm{ATP}}$ in $\beta$-cells. The closing of $\mathrm{K}_{\mathrm{ATP}}$ is a key step in glucose-induced insulin secretion. At low glucose levels calcium channels are closed and $\mathrm{K}_{\mathrm{ATP}}$ channels open, and potassium ions $\left(\mathrm{K}^{+}\right)$can flow into $\beta$-cells, while at high glucose levels $\mathrm{K}_{\mathrm{ATP}}$ channels close and L-type calcium channels are opened. The flow of calcium ions $\left(\mathrm{Ca}^{2+}\right)$ into $\beta$-cells induces insulin secretion (Fridlyand et al. 2013, Jia et al. 2015). Regardless of the presence or absence of ER $\alpha$, estrogens reduce the permeability of $\mathrm{K}_{\mathrm{ATP}}$, which stimulates insulin secretion. However, in the absence of ER $\beta$ estrogens lose their ability to affect $K_{\text {ATP }}$ permeability. $K_{\text {ATP }}$ channels also contribute to the regulation of blood flow in arteries, and with increasing age the response of $\mathrm{K}_{\mathrm{ATP}}$ channels to agonists declines, and vasoreactivity along with it. In heart $\mathrm{K}_{\mathrm{ATP}}$ channels, there is an age-related decline in surface density and an increase in sensitivity to adenosine triphosphate (ATP), which lowers the adaptivity to stress impulses such as physical strain and cardiac ischemia (Yang et al. 2016).

\subsubsection{Kir $_{2.3}$ channels}

$\mathrm{Kir}_{2.3}$ channels are an important subfamily of $\mathrm{K}_{\mathrm{ir}}$ channels, produced mainly in the forebrain, an area associated with cognitive abilities, memory, emotions, but also with neuropsychiatric disorders. It has been shown that age dependent steroids PregS and to a lesser extend DHEAS are important positive modulators of $\mathrm{K}_{\mathrm{ir}}$ channels (Kobayashi et al. 2009).

\subsubsection{Calcium-activated potassium channels}

3.3.6.1. Mitochondrial BKCa channels (large-conductance voltage- and calcium-activated $K^{+}$channels)

Aging leads to the downregulation of $\mathrm{BKCa}$ channels in coronary arteries, resulting in a decline in vasodilation and an increase in the risk of coronary disease. This trend can be reduced by lowintensity physical exercise (Albarwani et al. 2010). BKCa channels in the circulatory system are modulated by endogenous compounds such as angiotensin II, high levels of glucose, and arachidonic acid brought on by oxidative stress. This mechanism contributes to the development of DM2 (Albarwani et al. 2010, Hermann et al. 2015). BKCa channels are also connected to the physiology of sleep and hearing. Activators of BKCa can be protective in the heart circulatory system (Bentzen et al. 2014).

\subsubsection{SKCa channels (small-conductance $\mathrm{Ca}^{2+}$-activated} $K^{+}$channels)

SKCa channels are a subfamily of calciumactivated potassium channels. Calcium does not bind directly to the $\mathrm{SKCa}$ channels, but $\mathrm{Ca}^{2+}$ binds to the protein calmodulin, which changes conformation and leads to SKCa opening (Adelman et al. 2012). SKCa channels are activated by type $\mathrm{N}$ calcium channels and allow potassium ions to pass the cellular membrane. SKCas are expressed in CNS tissue, and are associated with synaptic plasticity, playing an important role in learning and memory. Increased expression of SKCA with age contributes to reductions in LTP and cognitive abilities (Blank et al. 2003, Stackman et al. 2002). SKCa regulates glucose-activated action potentials in pancreatic $\beta$-cells (Jacobson et al. 2010).

\subsubsection{L-type voltage gated calcium channels (VGCCs)}

These channels are responsible for the excitation 
of cells in skeletal, smooth, and heart muscle, and for the secretion of aldosterone (Felizola et al. 2014, Wang et al. 2004). Similarly to $K_{\text {ATP }}$, they play an important role in the pathophysiology of diabetes (Fridlyand et al. 2013, Jia et al. 2015). With increasing age there is an increase in the flow of calcium ions and an increase in the expression of L-type VGCCs, which is related to disorders in neuronal activity, cognitive decline, and particularly to a worsening of contextual and emotional memory (Zanos et al. 2015).

\subsubsection{Transient receptor potential channels (TRPs)}

TRPM channels (TRPV1, TRPV2, TRPM2, TRPM4 and TRPM5) direct insulin secretion and glucose homeostasis through the flow of $\mathrm{Ca}^{2+}$ ions, metabolites of nicotinamide adenine dinucleotide (NAD), or hormoneactivated hormone receptors. TRPV2 contributes not only to insulin secretion, but also to cellular proliferation. At the same time, it is regulated in an autocrine manner by insulin (Dhakal and Lee 2019, Uchida and Tominaga 2011).

TRPA1 receptors play an important role in detecting potentially dangerous compounds. Similarly as with TRPV1 activation, activation of TRPA1 in humans produces pain (Heber et al. 2019). TRPA1 receptors also play a key role in the pathogenesis of $\mathrm{AD}$ (Lee et al. 2016).

Capsaicin receptors (TRPV1) are expressed in spinal ganglia, and carry stimuli from their endings in the periphery to the CNS (Cho et al. 2002). PregS inhibits TRPV1 receptors at the peripheral level, and another $\Delta^{5}$ steroid DHEA and its reduced metabolites epiandrosterone and etiocholanolone inhibit the transfer of capsaicin-induced pain, independently of the opioid and cannabinoid system (Chen et al. 2004, Chen et al. 2006). TRPV1, in sensory neurons, is associated with pathophysiological $\beta$-cell inflammation. In addition, TRPV1-TRPV4 receptors inhibit adipogenesis (Dhakal and Lee 2019, Uchida and Tominaga 2011).

Activation of capsaicin receptors in young mice inhibits the production of tumor necrotic factor $\alpha(\mathrm{TNF} \alpha)$, and thus weakens inflammatory processes. On the other hand, in older animals this has a negative impact, as lower TNF $\alpha$ leads to a weakened immune response, inhibiting the organism's ability to protect itself against microbial infection (Wanner et al. 2012). Mice lacking TRPV1 receptors have been shown to live longer, and in old age had metabolic profiles typical for younger individuals. TRPV1-KO mice, this also lowered the production of the CGRP neuropeptide from sensory endings innervating Langerhans islands and subsequently stimulating insulin secretion (Riera et al. 2014).

TRPM3 channels also play an important role in stimulating the activity of pancreatic $\beta$-cells and the subsequent insulin secretion (Wagner et al. 2008). As for relationships to aging, these channels are positively and rapidly reversibly modulated by age-dependent sulfates of $\Delta^{5}$ steroids such as PregS and to a lesser extent DHEAS (Havlikova et al. 2002, Sulcova et al. 1997, Wagner et al. 2008).

TRPC5 channels are expressed primarily in the brain. These excitatory non-selective cation channels are regulated with G-protein and phospholipase C (PLC) coupled proteins and they potentiate responses to fear. It is known that TRPC5-KO mice show lowered levels of natural fear to pain stimuli (Riccio et al. 2009). The extracellular application of sex and age-related endogenous steroids such as PregS, pregnanolone sulfate, pregnanolone, progesterone, and dihydrotestosterone inhibits the activity of TRPC5 for 1-2 min while DHEAS and estradiol have a weaker inhibitory effect (Majeed et al. 2011).

\section{4. $\sigma 1$ receptors $(\sigma 1 R s)$}

$\sigma 1 \mathrm{Rs}$ are in the membrane-associated protein family. They are distributed mainly in the CNS in neurons, astrocytes, oligodendrocytes, and microglial cells. $\sigma 1 \mathrm{R}$ is able to bind to a range of pharmacologically active compounds, such as antipsychotics, opioids, antidepressants, antagonists of muscarine, D2 dopamine and N-methyl-D-aspartate (NMDA) receptor ligands, monoamine transport inhibitors, selective serotonin reuptake inhibitors, and monoamine oxidase inhibitors. After activation, $\sigma 1 \mathrm{R}$ is able to translocate to other cellular compartments and bind to membrane proteins including ion channels, kinases, transmembrane receptors, and receptors for tropic factors. The $\sigma 1 \mathrm{R}$ primarily strengthens glutamatergic synapses, cholinergic synapses, and increases the activity of tropic factors, particularly brain-derived neurotropic factor (BDNF), which is a key component of memory. Cholinergic neurons in the forebrain innervate the grey matter, amygdaloid complex and the HC, which are important for forming memories. The activity of $\sigma 1 \mathrm{R}$ indirectly influences cholinergic pathways through the modulation of NMDARs in the HC, septum and cortex, but also directly, as agonists of $\sigma 1 \mathrm{R}$ modulate the release of acetylcholine. This depends on $\sigma 1 \mathrm{R}$ stimulating the 
mobilization of calcium ions through modulation of IP3 receptors and voltage-gated $\mathrm{K}^{+}$and $\mathrm{Ca}^{2+}$ channels.

During healthy aging, there is no change in the binding potential of $\sigma 1 \mathrm{R}$. Nevertheless, $\sigma 1 \mathrm{R}$ is a target of neuroprotective therapy for $\mathrm{AD}$ and other neurodegenerative diseases. In addition, recent studies have found lower densities of $\sigma 1 \mathrm{R}$ in the brains of $\mathrm{AD}$ patients than in age-matched controls. Moreover, some steroid agonists of $\sigma 1 \mathrm{R}$ such as PregS protect pyramidal cells in the HC from loss due to application of the neurotoxic amyloid $\beta$-peptide fragment in rats (see review Maurice and Goguadze 2017).

\section{Anti-glucocorticoid immunoprotective steroids}

$\Delta^{5} \mathrm{C} 19$ steroids, their $7 \alpha / \beta-7$-oxo- and $16 \alpha$ hydroxy-metabolites in particular, are well known as antiglucocorticoid and immunoprotective substances (Ahlem et al. 2011, Hennebert et al. 2009, Sterzl et al. 2017). In our recent study (Honcu et al. 2019) focused on the influence of age on the steroid metabolome and possible improvements using lifestyle changes and spa therapies, results obtained on changes to the steroid metabolome and somatic, psychosomatic, and psychic parameters have allowed us to model the relationships between age and steroidogenesis, the relationships between steroidogenesis and somatic, psychosomatic and psychic indicators, as well as the possible positive reversible changes achievable. Initial levels of immunoprotective steroids were positively correlated with declines in somatic and psychosomatic symptoms and total score on the N-5 neurotic questionnaire (Honcu et al. 2019). These results indicate that at the least, the activity of the ZR was increased after intervention, and its activity at the start of treatment predicted the improvement of somatic and psychosomatic components of the N-5 questionnaire. In addition to these bioactive compounds, other adrenal C19 steroids and their $5 \alpha / \beta$-reduced metabolites showed similar relationships with the decline in somatic and psychosomatic symptoms after intervention. As mentioned above, levels of $\Delta^{5} \mathrm{C} 19$ steroids are markedly agedependent (Hampl et al. 2001, Sulcova et al. 1997), and over life they are closely associated with cell death in the ZR (Staton et al. 2004). Therefore, the increase in circulating $\mathrm{C} 19$ steroids (and their $5 \alpha / \beta$-reduced metabolites) after physical activity and an appropriate lifestyle in $50+$ women resulted in their ZR becoming “younger" (Bicikova et al. 2018, Honcu et al. 2019).

\section{Conclusions}

In this review work, we focused on hormonal changes accompanying aging in relation to functional changes in their receptors, both at peripheral and central levels. The emphasis was particularly on the role of small molecules in these changes. We also discussed the physiological and pathophysiological consequences of these changes mostly linked to changes in hypothalamicpituitary-adrenal axis (HPAA) with regard to the possible treatment of certain impairments accompanying aging. The data available in the literature, including our own, suggest that unwanted changes associated with ageing can be slowed, stopped and, in some cases, reversed by appropriate treatment, but in particular by lifemanagement adjustment.

\section{Conflict of Interest}

There is no conflict of interest.

\section{Acknowledgements}

This article is dedicated to the jubilee of the doyen of the Czechoslovak steroid endocrinology Professor Luboslav Stárka. Grants GAČR ID 17-25710S "Basic research of balance changes in seniors" by the Czech Science Foundation, NV17-30528A Prediction of gestational diabetes on the basis of steroid metabolism and NV1801-00399: Neuroactively acting hormones in cerebrospinal fluid and serum - use for early prediction of Alzheimer's disease from the Czech Research Health Council, and MH CZ - DRO (Institute of Endocrinology EÚ, 00023761) supported this review.

\section{References}

ADELMAN JP, MAYLIE J, SAH P: Small-conductance Ca2+-activated K+ channels: form and function. Annu Rev Physiol 74: 245-269, 2012. https://doi.org/10.1146/annurev-physiol-020911-153336

AHLEM CN, AUCI DL, NICOLETTI F, PIETERS R, KENNEDY MR, PAGE TM, READING CL, ENIOUTINA EY, FRINCKE JM: Pharmacology and immune modulating properties of 5-androstene-3beta,7beta,17beta-triol, a DHEA metabolite in the human metabolome. J Steroid Biochem Mol Biol 126: 87-94, 2011. https://doi.org/10.1016/j.jsbmb.2011.04.010 
ALBARWANI S, AL-SIYABI S, BAOMAR H, HASSAN MO: Exercise training attenuates ageing-induced BKCa channel downregulation in rat coronary arteries. Exp Physiol 95: 746-755, 2010. https://doi.org/10.1113/expphysiol.2009.051250

ATZMON G, BARZILAI N, SURKS MI, GABRIELY I: Genetic predisposition to elevated serum thyrotropin is associated with exceptional longevity. J Clin Endocrinol Metab 94: 4768-4775, 2009. https://doi.org/10.1210/jc.2009-0808

AUYEUNG TW, LEE JS, KWOK T, LEUNG J, OHLSSON C, VANDENPUT L, LEUNG PC, WOO J: Testosterone but not estradiol level is positively related to muscle strength and physical performance independent of muscle mass: a cross-sectional study in 1489 older men. Eur J Endocrinol 164: 811-817, 2011. https://doi.org/10.1530/EJE-10-0952

BAE YJ, ZEIDLER R, BABER R, VOGEL M, WIRKNER K, LOEFFLER M, CEGLAREK U, KIESS W, KORNER A, THIERY J, KRATZSCH J: Reference intervals of nine steroid hormones over the life-span analyzed by LC-MS/MS: effect of age, gender, puberty, and oral contraceptives. J Steroid Biochem Mol Biol 193: 105409, 2019. https://doi.org/10.1016/j.jsbmb.2019.105409

BALACHANDRAN A, DE BEER J, JAMES KS, VAN WISSEN L, JANSSEN F: Comparison of population aging in Europe and Asia using a time-consistent and comparative aging measure. J Aging Health 32: 340-351, 2020. https://doi.org/10.1177/0898264318824180

BELELLI D, LAMBERT JJ, PETERS JA, GEE KW, LAN NC: Modulation of human recombinant GABAA receptors by pregnanediols. Neuropharmacology 35: 1223-1231, 1996. https://doi.org/10.1016/S0028-3908(96)00066-4

BENTZEN BH, OLESEN SP, RONN LC, GRUNNET M: BK channel activators and their therapeutic perspectives. Front Physiol 5: 389, 2014. https://doi.org/10.3389/fphys.2014.00389

BICIKOVA M, MACOVA L, KOLATOROVA L, HILL M, NOVOTNY J, JANDOVA D, STARKA L: Physiological changes after spa treatment - a focus on endocrinology. Physiol Res 67 (Suppl 3): S525-S530, 2018. https://doi.org/10.33549/physiolres.934016

BIONDI B, BARTALENA L, COOPER DS, HEGEDUS L, LAURBERG P, KAHALY GJ: The 2015 European Thyroid Association Guidelines on diagnosis and treatment of endogenous subclinical hyperthyroidism. Eur Thyroid J 4: 149-163, 2015. https://doi.org/10.1159/000438750

BLANK T, NIJHOLT I, KYE MJ, RADULOVIC J, SPIESS J: Small-conductance, Ca2+-activated K+ channel SK3 generates age-related memory and LTP deficits. Nat Neurosci 6: 911-912, 2003. https://doi.org/10.1038/nn1101

BOWERS J, TERRIEN J, CLERGET-FROIDEVAUX MS, GOTHIE JD, ROZING MP, WESTENDORP RG, VAN HEEMST D, DEMENEIX BA: Thyroid hormone signaling and homeostasis during aging. Endocr Rev 34: 556-589, 2013. https://doi.org/10.1210/er.2012-1056

BREMNER AP, FEDDEMA P, LEEDMAN PJ, BROWN SJ, BEILBY JP, LIM EM, WILSON SG, O'LEARY PC, WALSH JP: Age-related changes in thyroid function: a longitudinal study of a community-based cohort. J Clin Endocrinol Metab 97: 1554-1562, 2012. https://doi.org/10.1210/jc.2011-3020

CAPPOLA AR, XUE QL, WALSTON JD, LENG SX, FERRUCCI L, GURALNIK J, FRIED LP: DHEAS levels and mortality in disabled older women: the Women's Health and Aging Study I. J Gerontol A Biol Sci Med Sci 61: 957-962, 2006. https://doi.org/10.1093/gerona/61.9.957

CARRER P, TREVISAN C, FRANCHIN A, VOLPE ED, RANCAN A, ZANFORLINI BM, MAGGI S, NOALE M, CORTI MC, PERISSINOTTO E, MANZATO E, SERGI G: Dehydroepiandrosterone sulfate and fall risk in older people: sex differences in the Pro.V.A. longitudinal study. Maturitas 128: 43-48, 2019. https://doi.org/10.1016/j.maturitas.2019.07.003

CASPARY DM, LING L, TURNER JG, HUGHES LF: Inhibitory neurotransmission, plasticity and aging in the mammalian central auditory system. J Exp Biol 211: 1781-1791, 2008. https://doi.org/10.1242/jeb.013581

CHAKER L, KOREVAAR TI, MEDICI M, UITTERLINDEN AG, HOFMAN A, DEHGHAN A, FRANCO OH, PEETERS RP: Thyroid function characteristics and determinants: The Rotterdam Study. Thyroid 26: $1195-$ 1204, 2016. https://doi.org/10.1089/thy.2016.0133 
CHATTERJEE S, MONDAL S: Effect of regular yogic training on growth hormone and dehydroepiandrosterone sulfate as an endocrine marker of aging. Evid Based Complement Alternat Med 2014: 240581, 2014. https://doi.org/10.1155/2014/240581

CHEN R, XU P, SONG P, WANG M, HE J: China has faster pace than Japan in population aging in next 25 years. Biosci Trends 13: 287-291, 2019. https://doi.org/10.5582/bst.2019.01213

CHEN SC, CHANG TJ, WU FS: Competitive inhibition of the capsaicin receptor-mediated current by dehydroepiandrosterone in rat dorsal root ganglion neurons. J Pharmacol Exp Ther 311: 529-536, 2004. https://doi.org/10.1124/jpet.104.069096

CHEN SC, LIU BC, CHEN CW, WU FS: Intradermal pregnenolone sulfate attenuates capsaicin-induced nociception in rats. Biochem Biophys Res Commun 349: 626-633, 2006. https://doi.org/10.1016/j.bbrc.2006.08.076

CHO H, SHIN J, SHIN CY, LEE SY, OH U: Mechanosensitive ion channels in cultured sensory neurons of neonatal rats. J Neurosci 22: 1238-1247, 2002. https://doi.org/10.1523/JNEUROSCI.22-04-01238.2002

CLAYTON DA, GROSSHANS DR, BROWNING MD: Aging and surface expression of hippocampal NMDA receptors. J Biol Chem 277: 14367-14369, 2002. https://doi.org/10.1074/jbc.C200074200

DE KLOET ER, MEIJER OC, DE NICOLA AF, DE RIJK RH, JOELS M: Importance of the brain corticosteroid receptor balance in metaplasticity, cognitive performance and neuro-inflammation. Front Neuroendocrinol 49: 124-145, 2018. https://doi.org/10.1016/j.yfrne.2018.02.003

DHAKAL S, LEE Y: Transient receptor potential channels and metabolism. Mol Cells 42: 569-578, 2019. https://doi.org/10.14348/molcells.2019.0007

DHARIA S, SLANE A, JIAN M, CONNER M, CONLEY AJ, BRISSIE RM, PARKER CR JR: Effects of aging on cytochrome b5 expression in the human adrenal gland. J Clin Endocrinol Metab 90: 4357-4361, 2005. https://doi.org/10.1210/jc.2005-0017

ELABD C, COUSIN W, UPADHYAYULA P, CHEN RY, CHOOLJIAN MS, LI J, KUNG S, JIANG KP, CONBOY IM: Oxytocin is an age-specific circulating hormone that is necessary for muscle maintenance and regeneration. Nat Commun 5: 4082, 2014. https://doi.org/10.1038/ncomms5082

EROL A: The functions of PPARs in aging and longevity. PPAR Res 2007: 39654, 2007. https://doi.org/10.1155/2007/39654

ESLER M, LAMBERT G, KAYE D, RUMANTIR M, HASTINGS J, SEALS DR: Influence of ageing on the sympathetic nervous system and adrenal medulla at rest and during stress. Biogerontology 3: 45-49, 2002. https://doi.org/10.1023/A:1015203328878

FELIZOLA SJ, MAEKAWA T, NAKAMURA Y, SATOH F, ONO Y, KIKUCHI K, ARITOMI S, IKEDA K, YOSHIMURA M, TOJO K, SASANO H: Voltage-gated calcium channels in the human adrenal and primary aldosteronism. J Steroid Biochem Mol Biol 144: 410-416, 2014. https://doi.org/10.1016/j.jsbmb.2014.08.012

FRIDLYAND LE, JACOBSON DA, PHILIPSON LH: Ion channels and regulation of insulin secretion in human betacells: a computational systems analysis. Islets 5: 1-15, 2013. https://doi.org/10.4161/isl.24166

GARCIA M, SEELAENDER M, SOTIROPOULOS A, COLETTI D, LANCHA AH JR: Vitamin D, muscle recovery, sarcopenia, cachexia, and muscle atrophy. Nutrition 60: 66-69, 2019. https://doi.org/10.1016/j.nut.2018.09.031

GARG A, ZHAO A, ERICKSON SL, MUKHERJEE S, LAU AJ, ALSTON L, CHANG TK, MANI S, HIROTA SA: Pregnane $\mathrm{X}$ receptor activation attenuates inflammation-associated intestinal epithelial barrier dysfunction by inhibiting cytokine-induced myosin light-chain kinase expression and c-Jun N-terminal kinase 1/2 activation. J Pharmacol Exp Ther 359: 91-101, 2016. https://doi.org/10.1124/jpet.116.234096

GORINI S, KIM SK, INFANTE M, MAMMI C, LA VIGNERA S, FABBRI A, JAFFE IZ, CAPRIO M: Role of aldosterone and mineralocorticoid receptor in cardiovascular aging. Front Endocrinol (Lausanne) 10: 584, 2019. https://doi.org/10.3389/fendo.2019.00584

HAMMERMAN MR: Insulin-like growth factors and aging. Endocrinol Metab Clin North Am 16: 995-1011, 1987. https://doi.org/10.1016/S0889-8529(18)30455-9

HAMPL R, HILL M, STARKA L: 7-Hydroxydehydroepiandrosterone epimers in the life span. J Steroid Biochem Mol Biol 78: 367-372, 2001. https://doi.org/10.1016/S0960-0760(01)00108-X 
HAVLIKOVA H, HILL M, HAMPL R, STARKA L: Sex- and age-related changes in epitestosterone in relation to pregnenolone sulfate and testosterone in normal subjects. J Clin Endocrinol Metab 87: 2225-2231, 2002. https://doi.org/10.1210/jcem.87.5.8499

HEBER S, GOLD-BINDER M, CIOTU CI, WITEK M, NINIDZE N, KRESS HG, FISCHER MJM: A human TRPA1-specific pain model. J Neurosci 39: 3845-3855, 2019. https://doi.org/10.1523/JNEUROSCI.3048$\underline{18.2019}$

HENNEBERT O, MONTES M, FAVRE-REGUILLON A, CHERMETTE H, FERROUD C, MORFIN R: Epimerase activity of the human 11beta-hydroxysteroid dehydrogenase type 1 on 7-hydroxylated C19-steroids. J Steroid Biochem Mol Biol 114: 57-63, 2009. https://doi.org/10.1016/j.jsbmb.2008.12.015

HERMANN A, SITDIKOVA GF, WEIGER TM: Oxidative stress and maxi calcium-activated potassium (BK) channels. Biomolecules 5: 1870-1911, 2015. https://doi.org/10.3390/biom5031870

HILL M, LUKAC D, LAPCIK O, SULCOVA J, HAMPL R, POUZAR V, STARKA L: Age relationships and sex differences in serum levels of pregnenolone and 17-hydroxypregnenolone in healthy subjects. Clin Chem Lab Med 37: 439-447, 1999. https://doi.org/10.1515/CCLM.1999.072

HILL M, PARIZEK A, KANCHEVA R, JIRASEK JE: Reduced progesterone metabolites in human late pregnancy. Physiol Res 60: 225-241, 2011. https://doi.org/10.33549/physiolres.932077

HONCU P, HILL M, BICIKOVA M, JANDOVA D, VELIKOVA M, KAJZAR J, KOLATOROVA L, BESTAK J, MACOVA L, KANCHEVA R, KREJCI M, NOVOTNY J, STARKA L: Activation of adrenal steroidogenesis and an improvement of mood balance in postmenopausal females after spa treatment based on physical activity. Int J Mol Sci 20: 2019. https://doi.org/10.3390/ijms20153687

IBANEZ L, POTAU N, MARCOS MV, DE ZEGHER F: Corticotropin-releasing hormone as adrenal androgen secretagogue. Pediatr Res 46: 351-353, 1999a. https://doi.org/10.1203/00006450-199909000-00018

IBANEZ L, POTAU N, MARCOS MV, DE ZEGHER F: Corticotropin-releasing hormone: a potent androgen secretagogue in girls with hyperandrogenism after precocious pubarche. J Clin Endocrinol Metab 84: 4602-4606, 1999b. https://doi.org/10.1210/jc.84.12.4602

JACOBSON DA, MENDEZ F, THOMPSON M, TORRES J, COCHET O, PHILIPSON LH: Calcium-activated and voltage-gated potassium channels of the pancreatic islet impart distinct and complementary roles during secretagogue induced electrical responses. J Physiol 588: 3525-3537, 2010. https://doi.org/10.1113/jphysiol.2010.190207

JIA M, DAHLMAN-WRIGHT K, GUSTAFSSON JA: Estrogen receptor alpha and beta in health and disease. Best Pract Res Clin Endocrinol Metab 29: 557-568, 2015. https://doi.org/10.1016/j.beem.2015.04.008

JIANG P, YANG CX, WANG YT, XU TL: Mechanisms of modulation of pregnanolone on glycinergic response in cultured spinal dorsal horn neurons of rat. Neuroscience 141: 2041-2050, 2006. https://doi.org/10.1016/j.neuroscience.2006.05.009

JURADO S: AMPA receptor trafficking in natural and pathological aging. Front Mol Neurosci 10: 446, 2017. https://doi.org/10.3389/fnmol.2017.00446

JURE I, DE NICOLA A, LABOMBARDA F: Progesterone effects on the oligodendrocyte linage: all roads lead to the progesterone receptor. Neural Regen Res 14: 2029-2034, 2019. https://doi.org/10.4103/1673-5374.262570

KALAMIDA D, POULAS K, AVRAMOPOULOU V, FOSTIERI E, LAGOUMINTZIS G, LAZARIDIS K, SIDERI A, ZOURIDAKIS M, TZARTOS SJ: Muscle and neuronal nicotinic acetylcholine receptors. Structure, function and pathogenicity. FEBS J 274: 3799-3845, 2007. https://doi.org/10.1111/j.1742-4658.2007.05935.x

KARRER TM, JOSEF AK, MATA R, MORRIS ED, SAMANEZ-LARKIN GR: Reduced dopamine receptors and transporters but not synthesis capacity in normal aging adults: a meta-analysis. Neurobiol Aging 57: 36-46, 2017. https://doi.org/10.1016/j.neurobiolaging.2017.05.006

KE L, LUKAS RJ: Effects of steroid exposure on ligand binding and functional activities of diverse nicotinic acetylcholine receptor subtypes. J Neurochem 67: 1100-1112, 1996. https://doi.org/10.1046/j.14714159.1996.67031100.x

KLIEWER SA, GOODWIN B, WILLSON TM: The nuclear pregnane X receptor: a key regulator of xenobiotic metabolism. Endocr Rev 23: 687-702, 2002. https://doi.org/10.1210/er.2001-0038 
KOBAYASHI T, WASHIYAMA K, IKEDA K: Pregnenolone sulfate potentiates the inwardly rectifying K channel Kir2.3. PLoS One 4: e6311, 2009. https://doi.org/10.1371/journal.pone.0006311

KODAMA S, NEGISHI M: Sulfotransferase genes: regulation by nuclear receptors in response to xeno/endo-biotics. Drug Metab Rev 45: 441-449, 2013. https://doi.org/10.3109/03602532.2013.835630

KONG SH, KIM JH, LEE JH, HONG AR, SHIN CS, CHO NH: Dehydroepiandrosterone sulfate and free testosterone but not estradiol are related to muscle strength and bone microarchitecture in older adults. Calcif Tissue Int 105: 285-293, 2019. https://doi.org/10.1007/s00223-019-00566-5

KUMAR A: NMDA Receptor function during senescence: implication on cognitive performance. Front Neurosci 9: 473, 2015. https://doi.org/10.3389/fnins.2015.00473

LABRIE F, BELANGER A, PELLETIER G, MARTEL C, ARCHER DF, UTIAN WH: Science of intracrinology in postmenopausal women. Menopause 24: 702-712, 2017. https://doi.org/10.1097/GME.0000000000000808

LEE KI, LEE HT, LIN HC, TSAY HJ, TSAI FC, SHYUE SK, LEE TS: Role of transient receptor potential ankyrin 1 channels in Alzheimer's disease. J Neuroinflammation 13: 92, 2016. https://doi.org/10.1186/s12974-016-0557-Z

LI CW, YU K, SHYH-CHANG N, LI GX, JIANG LJ, YU SL, XU LY, LIU RJ, GUO ZJ, XIE HY, LI RR, YING J, LI K, LI DJ: Circulating factors associated with sarcopenia during ageing and after intensive lifestyle intervention. J Cachexia Sarcopenia Muscle 10: 586-600, 2019. https://doi.org/10.1002/jcsm.12417

LI P, BRACAMONTES J, KATONA BW, COVEY DF, STEINBACH JH, AKK G: Natural and enantiomeric etiocholanolone interact with distinct sites on the rat alpha1beta2gamma2L GABAA receptor. Mol Pharmacol 71: 1582-1590, 2007. https://doi.org/10.1124/mol.106.033407

LI Y, SUN H, CHEN Z, XU H, BU G, ZHENG H: Implications of GABAergic neurotransmission in Alzheimer's disease. Front Aging Neurosci 8: 31, 2016. https://doi.org/10.3389/fnagi.2016.00031

LUNDGREN P, STROMBERG J, BACKSTROM T, WANG M: Allopregnanolone-stimulated GABA-mediated chloride ion flux is inhibited by 3beta-hydroxy-5alpha-pregnan-20-one (isoallopregnanolone). Brain Res 982: 45-53, 2003. https://doi.org/10.1016/S0006-8993(03)02939-1

MAJEED Y, AMER MS, AGARWAL AK, MCKEOWN L, PORTER KE, O'REGAN DJ, NAYLOR J, FISHWICK $\mathrm{CW}$, MURAKI K, BEECH DJ: Stereo-selective inhibition of transient receptor potential TRPC5 cation channels by neuroactive steroids. Br J Pharmacol 162: 1509-1520, 2011. https://doi.org/10.1111/j.14765381.2010.01136.X

MAKSAY G, LAUBE B, BETZ H: Subunit-specific modulation of glycine receptors by neurosteroids. Neuropharmacology 41: 369-376, 2001. https://doi.org/10.1016/S0028-3908(01)00071-5

MAURICE T, GOGUADZE N: Role of sigma1 receptors in learning and memory and Alzheimer's disease-type dementia. Adv Exp Med Biol 964: 213-233, 2017. https://doi.org/10.1007/978-3-319-50174-1_15

MELMED S: Functional anatomy of the hypothalamic pituitary axis. In: The Pituitary. MELMED S (ed.), Academic Press, Los Angeles, 2011, $744 \mathrm{p}$.

MOONEY RA, CIRILLO J, BYBLOW WD: GABA and primary motor cortex inhibition in young and older adults: a multimodal reliability study. J Neurophysiol 118: 425-433, 2017. https://doi.org/10.1152/jn.00199.2017

MORA F, SEGOVIA G, DEL ARCO A: Glutamate-dopamine-GABA interactions in the aging basal ganglia. Brain Res Rev 58: 340-353, 2008. https://doi.org/10.1016/j.brainresrev.2007.10.006

MULLUR R, LIU YY, BRENT GA: Thyroid hormone regulation of metabolism. Physiol Rev 94: 355-382, 2014. https://doi.org/10.1152/physrev.00030.2013

NAKAMURA Y, HORNSBY PJ, CASSON P, MORIMOTO R, SATOH F, XING Y, KENNEDY MR, SASANO H, RAINEY WE: Type 5 17beta-hydroxysteroid dehydrogenase (AKR1C3) contributes to testosterone production in the adrenal reticularis. J Clin Endocrinol Metab 94: 2192-2198, 2009. https://doi.org/10.1210/jc.2008-2374

NANBA K, VAIDYA A, WILLIAMS GH, ZHENG I, ELSE T, RAINEY WE: Age-related autonomous aldosteronism. Circulation 136: 347-355, 2017. https://doi.org/10.1161/CIRCULATIONAHA.117.028201

NANBA K, VAIDYA A, RAINEY WE: Aging and adrenal aldosterone production. Hypertension 71: 218-223, 2018. https://doi.org/10.1161/HYPERTENSIONAHA.117.10391

NEWCOMER JW, FARBER NB, OLNEY JW: NMDA receptor function, memory, and brain aging. Dialogues Clin Neurosci 2: 219-232, 2000. 
O'DONNELL AB, TRAVISON TG, HARRIS SS, TENOVER JL, MCKINLAY JB: Testosterone, dehydroepiandrosterone, and physical performance in older men: results from the Massachusetts Male Aging Study. J Clin Endocrinol Metab 91: 425-431, 2006. https://doi.org/10.1210/jc.2005-1227

OHLSSON C, NETHANDER M, KARLSSON MK, ROSENGREN BE, RIBOM E, MELLSTROM D, VANDENPUT L: Serum DHEA and its sulfate are associated with incident fall risk in older men: The MrOS Sweden Study. J Bone Miner Res 33: 1227-1232, 2018. https://doi.org/10.1002/jbmr.3418

OMAR HR, KOMAROVA I, EL-GHONEMI M, FATHY A, RASHAD R, ABDELMALAK HD, YERRAMADHA MR, ALI Y, HELAL E, CAMPORESI EM: Licorice abuse: time to send a warning message. Ther Adv Endocrinol Metab 3: 125-138, 2012. https://doi.org/10.1177/2042018812454322

PARK-CHUNG M, MALAYEV A, PURDY RH, GIBBS TT, FARB DH: Sulfated and unsulfated steroids modulate gamma-aminobutyric acidA receptor function through distinct sites. Brain Res 830: 72-87, 1999. https://doi.org/10.1016/S0006-8993(99)01381-5

PICCIOTTO MR, ZOLI M: Nicotinic receptors in aging and dementia. J Neurobiol 53: 641-655, 2002. https://doi.org/10.1002/neu.10102

PIGNATTI E, LENG S, CARLONE DL, BREAULT DT: Regulation of zonation and homeostasis in the adrenal cortex. Mol Cell Endocrinol 441: 146-155, 2017. https://doi.org/10.1016/j.mce.2016.09.003

POP GM, CRIVII C, OPINCARIU I: Anatomy and function of the hypothalamus. In: Hypothalamus in Health and Diseases. BALOYANNIS SJ, GORDELADZE J (eds), Intech Open Ltd., London, Rijeka, 2018.

RAHMAN M, LINDBLAD C, JOHANSSON IM, BACKSTROM T, WANG MD: Neurosteroid modulation of recombinant rat alpha5beta2gamma2L and alpha1beta2gamma2L GABA(A) receptors in Xenopus oocyte. Eur J Pharmacol 547: 37-44, 2006. https://doi.org/10.1016/j.ejphar.2006.07.039

RATNER MH, KUMARESAN V, FARB DH: Neurosteroid actions in memory and neurologic/neuropsychiatric disorders. Front Endocrinol (Lausanne) 10: 169, 2019. https://doi.org/10.3389/fendo.2019.00169

RENDINA DN, RYFF CD, COE CL: Precipitous dehydroepiandrosterone declines reflect decreased physical vitality and function. J Gerontol A Biol Sci Med Sci 72: 747-753, 2017. https://doi.org/10.1093/gerona/glw135

RICCIO A, LI Y, MOON J, KIM KS, SMITH KS, RUDOLPH U, GAPON S, YAO GL, TSVETKOV E, RODIG SJ, VAN'T VEER A, MELONI EG, CARLEZON WA JR, BOLSHAKOV VY, CLAPHAM DE: Essential role for TRPC5 in amygdala function and fear-related behavior. Cell 137: 761-772, 2009. https://doi.org/10.1016/j.cell.2009.03.039

RIEBEN C, SEGNA D, DA COSTA BR, COLLET TH, CHAKER L, AUBERT CE, BAUMGARTNER C, ALMEIDA OP, HOGERVORST E, TROMPET S, MASAKI K, MOOIJAART SP, GUSSEKLOO J, PEETERS RP, BAUER DC, AUJESKY D, RODONDI N: Subclinical thyroid dysfunction and the risk of cognitive decline: a meta-analysis of prospective cohort studies. J Clin Endocrinol Metab 101: 4945-4954, 2016. https://doi.org/10.1210/jc.2016-2129

RIERA CE, HUISING MO, FOLLETT P, LEBLANC M, HALLORAN J, VAN ANDEL R, DE MAGALHAES FILHO CD, MERKWIRTH C, DILLIN A: TRPV1 pain receptors regulate longevity and metabolism by neuropeptide signaling. Cell 157: 1023-1036, 2014. https://doi.org/10.1016/j.cell.2014.03.051

RICHARDSON BD, BROZOSKI TJ, LING LL, CASPARY DM: Targeting inhibitory neurotransmission in tinnitus. Brain Res 1485: 77-87, 2012. https://doi.org/10.1016/j.brainres.2012.02.014

ROELFSEMA F, VAN HEEMST D, IRANMANESH A, TAKAHASHI P, YANG R, VELDHUIS JD: Impact of age, sex and body mass index on cortisol secretion in 143 healthy adults. Endocr Connect 6: 500-509, 2017. https://doi.org/10.1530/EC-17-0160

RUHS S, NOLZE A, HUBSCHMANN R, GROSSMANN C: 30 years of the mineralocorticoid receptor: nongenomic effects via the mineralocorticoid receptor. J Endocrinol 234: T107-T124, 2017. https://doi.org/10.1530/JOE$\underline{16-0659}$

SAKUMA K, YAMAGUCHI A: Sarcopenia and age-related endocrine function. Int J Endocrinol 2012: 127362, 2012. https://doi.org/10.1155/2012/127362

SALGADO S, KAPLITT MG: The nucleus accumbens: a comprehensive review. Stereotact Funct Neurosurg 93: 75-93, 2015. https://doi.org/10.1159/000368279 
SANTIAGO J, SILVA JV, ALVES MG, OLIVEIRA PF, FARDILHA M: Testicular aging: an overview of ultrastructural, cellular, and molecular alterations. J Gerontol A Biol Sci Med Sci 74: 860-871, 2019. https://doi.org/10.1093/gerona/gly082

SATO K, IEMITSU M: The role of dehydroepiandrosterone (DHEA) in skeletal muscle. Vitam Horm 108: 205-221, 2018. https://doi.org/10.1016/bs.vh.2018.03.002

SCHAEFER N, ROEMER V, JANZEN D, VILLMANN C: Impaired glycine receptor trafficking in neurological diseases. Front Mol Neurosci 11: 291, 2018. https://doi.org/10.3389/fnmol.2018.00291

SCHUMACHER M, MATTERN C, GHOUMARI A, OUDINET JP, LIERE P, LABOMBARDA F, SITRUK-WARE R, DE NICOLA AF, GUENNOUN R: Revisiting the roles of progesterone and allopregnanolone in the nervous system: resurgence of the progesterone receptors. Prog Neurobiol 113: 6-39, 2014. https://doi.org/10.1016/j.pneurobio.2013.09.004

SCHWARZ PB, PEEVER JH: Dopamine triggers skeletal muscle tone by activating D1-like receptors on somatic motoneurons. J Neurophysiol 106: 1299-1309, 2011. https://doi.org/10.1152/jn.00230.2011

SCIMECA M, CENTOFANTI F, CELI M, GASBARRA E, NOVELLI G, BOTTA A, TARANTINO U: Vitamin D receptor in muscle atrophy of elderly patients: a key element of osteoporosis-sarcopenia connection. Aging Dis 9: 952-964, 2018. https://doi.org/10.14336/AD.2018.0215

SECCIA TM, CAROCCIA B, GOMEZ-SANCHEZ EP, GOMEZ-SANCHEZ CE, ROSSI GP: The biology of normal zona glomerulosa and aldosterone-producing adenoma: pathological implications. Endocr Rev 39: 1029-1056, 2018. https://doi.org/10.1210/er.2018-00060

SEEVAGAN T, HULLIGAN S, PHULL J, ABOUMARZOUK OM: Testes structure and function. In: Blandy's Urology. ABOUMARZOUK OM (ed.), John Wiley \& Sons Ltd., Philadelphia, 2019. https://doi.org/10.1002/9781118863343.ch35

SEGNA D, BAUER DC, FELLER M, SCHNEIDER C, FINK HA, AUBERT CE, COLLET TH, DA COSTA BR, FISCHER K, PEETERS RP, CAPPOLA AR, BLUM MR, VAN DORLAND HA, ROBBINS J, NAYLOR K, EASTELL R, UITTERLINDEN AG, RIVADENEIRA RAMIREZ F, GOGAKOS A, GUSSEKLOO J, WILLIAMS GR, SCHWARTZ A, CAULEY JA, AUJESKY DA, BISCHOFF-FERRARI HA, RODONDI N, THYROID STUDIES C: Association between subclinical thyroid dysfunction and change in bone mineral density in prospective cohorts. J Intern Med 283: 56-72, 2018. https://doi.org/10.1111/joim.12688

SEGOVIA G, MORA F: Dopamine and GABA increases produced by activation of glutamate receptors in the nucleus accumbens are decreased during aging. Neurobiol Aging 26: 91-101, 2005. https://doi.org/10.1016/j.neurobiolaging.2004.02.023

SELMER C, OLESEN JB, HANSEN ML, VON KAPPELGAARD LM, MADSEN JC, HANSEN PR, PEDERSEN OD, FABER J, TORP-PEDERSEN C, GISLASON GH: Subclinical and overt thyroid dysfunction and risk of allcause mortality and cardiovascular events: a large population study. J Clin Endocrinol Metab 99: 2372-2382, 2014. https://doi.org/10.1210/jc.2013-4184

SIRIANNI R, MAYHEW BA, CARR BR, PARKER CR JR, RAINEY WE: Corticotropin-releasing hormone (CRH) and urocortin act through type $1 \mathrm{CRH}$ receptors to stimulate dehydroepiandrosterone sulfate production in human fetal adrenal cells. J Clin Endocrinol Metab 90: 5393-5400, 2005. https://doi.org/10.1210/jc.2005-0680

SOTTILE SY, LING L, COX BC, CASPARY DM: Impact of ageing on postsynaptic neuronal nicotinic neurotransmission in auditory thalamus. J Physiol 595: 5375-5385, 2017. https://doi.org/10.1113/JP274467

STACKMAN RW, HAMMOND RS, LINARDATOS E, GERLACH A, MAYLIE J, ADELMAN JP, TZOUNOPOULOS T: Small conductance Ca2+-activated $\mathrm{K}+$ channels modulate synaptic plasticity and memory encoding. J Neurosci 22: 10163-10171, 2002. https://doi.org/10.1523/JNEUROSCI.22-23-10163.2002

STATON BA, MIXON RL, DHARIA S, BRISSIE RM, PARKER CR JR: Is reduced cell size the mechanism for shrinkage of the adrenal zona reticularis in aging? Endocr Res 30: 529-534, 2004. https://doi.org/10.1081/ERC-200043617

STERZL I, HILL M, STARKA L, VELIKOVA M, KANCEVA R, JEMELKOVA J, CZERNEKOVA L, KOSZTYU P, ZADRAZIL J, MATOUSOVIC K, VONDRAK K, RASKA M: Patients with IgA nephropathy have altered levels of immunomodulatory C19 steroids. Glucocorticoid therapy with addition of adrenal androgens may be the choice. Physiol Res 66 (Suppl 3): S433-S442, 2017. https://doi.org/10.33549/physiolres.933732 
STRICH D, KARAVANI G, EDRI S, GILLIS D: TSH enhancement of FT4 to FT3 conversion is age dependent. Eur J Endocrinol 175: 49-54, 2016. https://doi.org/10.1530/EJE-16-0007

SULCOVA J, HILL M, HAMPL R, STARKA L: Age and sex related differences in serum levels of unconjugated dehydroepiandrosterone and its sulphate in normal subjects. $\mathrm{J}$ Endocrinol 154: 57-62, 1997. https://doi.org/10.1677/joe.0.1540057

SULLIVAN SD, MOENTER SM: Neurosteroids alter gamma-aminobutyric acid postsynaptic currents in gonadotropinreleasing hormone neurons: a possible mechanism for direct steroidal control. Endocrinology 144: 4366-4375, 2003. https://doi.org/10.1210/en.2003-0634

SURKS MI, ORTIZ E, DANIELS GH, SAWIN CT, COL NF, COBIN RH, FRANKLYN JA, HERSHMAN JM, BURMAN KD, DENKE MA, GORMAN C, COOPER RS, WEISSMAN NJ: Subclinical thyroid disease: scientific review and guidelines for diagnosis and management. JAMA 291: 228-238, 2004. https://doi.org/10.1001/jama.291.2.228

UCHIDA K, TOMINAGA M: The role of thermosensitive TRP (transient receptor potential) channels in insulin secretion. Endocr J 58: 1021-1028, 2011. https://doi.org/10.1507/endocrj.EJ11-0130

UNO Y, HOSAKA S, YAMAZAKI H: Identifcation and analysis of CYP7A1, CYP17A1, CYP20A1, CYP27A1 and CYP51A1 in cynomolgus macaques. J Vet Med Sci 76: 1647-1650, 2014. https://doi.org/10.1292/jvms.14$\underline{0313}$

VANKOVA M, HILL M, VELIKOVA M, VCELAK J, VACINOVA G, LUKASOVA P, VEJRAZKOVA D, DVORAKOVA K, RUSINA R, HOLMEROVA I, JAROLIMOVA E, VANKOVA H, BENDLOVA B: Reduced sulfotransferase SULT2A1 activity in patients with Alzheimer's disease. Physiol Res 64 (Suppl 2): S265-S273, 2015. https://doi.org/10.33549/physiolres.933160

VERMEULEN A: Dehydroepiandrosterone sulfate and aging. Ann N Y Acad Sci 774: 121-127, 1995. https://doi.org/10.1111/j.1749-6632.1995.tb17376.x

VINSON GP: Functional zonation of the adult mammalian adrenal cortex. Front Neurosci 10: 238, 2016. https://doi.org/10.3389/fnins.2016.00238

VYKLICKY V, KORINEK M, SMEJKALOVA T, BALIK A, KRAUSOVA B, KANIAKOVA M, LICHNEROVA K, CERNY J, KRUSEK J, DITTERT I, HORAK M, VYKLICKY L: Structure, function, and pharmacology of NMDA receptor channels. Physiol Res 63 (Suppl 1): S191-S203, 2014. https://doi.org/10.33549/physiolres.932678

WAGNER TF, LOCH S, LAMBERT S, STRAUB I, MANNEBACH S, MATHAR I, DUFER M, LIS A, FLOCKERZI V, PHILIPP SE, OBERWINKLER J: Transient receptor potential M3 channels are ionotropic steroid receptors in pancreatic beta cells. Nat Cell Biol 10: 1421-1430, 2008. https://doi.org/10.1038/ncb1801

WANG H, TURNER JG, LING L, PARRISH JL, HUGHES LF, CASPARY DM: Age-related changes in glycine receptor subunit composition and binding in dorsal cochlear nucleus. Neuroscience 160: 227-239, 2009. https://doi.org/10.1016/j.neuroscience.2009.01.079

WANG M, HE Y, EISENMAN LN, FIELDS C, ZENG CM, MATHEWS J, BENZ A, FU T, ZORUMSKI E, STEINBACH JH, COVEY DF, ZORUMSKI CF, MENNERICK S: 3beta -hydroxypregnane steroids are pregnenolone sulfate-like $\mathrm{GABA}(\mathrm{A})$ receptor antagonists. J Neurosci 22: 3366-3375, 2002. https://doi.org/10.1523/JNEUROSCI.22-09-03366.2002

WANG MC, DOLPHIN A, KITMITTO A: L-type voltage-gated calcium channels: understanding function through structure. FEBS Lett 564: 245-250, 2004. https://doi.org/10.1016/S0014-5793(04)00253-4

WANNER SP, GARAMI A, PAKAI E, OLIVEIRA DL, GAVVA NR, COIMBRA CC, ROMANOVSKY AA: Aging reverses the role of the transient receptor potential vanilloid-1 channel in systemic inflammation from antiinflammatory to proinflammatory. Cell Cycle 11: 343-349, 2012. https://doi.org/10.4161/cc.11.2.18772

WATAD A, BRAGAZZI NL, ADAWI M, AMITAL H, TOUBI E, PORAT BS, SHOENFELD Y: Autoimmunity in the elderly: insights from basic science and clinics - a mini-review. Gerontology 63: 515-523, 2017. https://doi.org/10.1159/000478012

WEIR CJ, LING AT, BELELLI D, WILDSMITH JA, PETERS JA, LAMBERT JJ: The interaction of anaesthetic steroids with recombinant glycine and GABAA receptors. $\mathrm{Br} \mathrm{J}$ Anaesth 92: 704-711, 2004. https://doi.org/10.1093/bja/aeh125 
WU FS, GIBBS TT, FARB DH: Inverse modulation of gamma-aminobutyric acid- and glycine-induced currents by progesterone. Mol Pharmacol 37: 597-602, 1990.

YANG HQ, SUBBOTINA E, RAMASAMY R, COETZEE WA: Cardiovascular KATP channels and advanced aging. Pathobiol Aging Age Relat Dis 6: 32517, 2016. https://doi.org/10.3402/pba.v6.32517

YIALLOURIS A, TSIOUTIS C, AGAPIDAKI E, ZAFEIRI M, AGOURIDIS AP, NTOURAKIS D, JOHNSON EO: Adrenal aging and its implications on stress responsiveness in humans. Front Endocrinol (Lausanne) 10: 54, 2019. https://doi.org/10.3389/fendo.2019.00054

ZANOS P, BHAT S, TERRILLION CE, SMITH RJ, TONELLI LH, GOULD TD: Sex-dependent modulation of age-related cognitive decline by the L-type calcium channel gene Cacnalc (Cav 1.2). Eur J Neurosci 42: 2499-2507, 2015. https://doi.org/10.1111/ejn.12952

ZHANG B, CHENG Q, OU Z, LEE JH, XU M, KOCHHAR U, REN S, HUANG M, PFLUG BR, XIE W: Pregnane $\mathrm{X}$ receptor as a therapeutic target to inhibit androgen activity. Endocrinology 151: 5721-5279, 2010. https://doi.org/10.1210/en.2010-0708

ZHAVORONKOV A, BHULLAR B: Classifying aging as a disease in the context of ICD-11. Front Genet 6: 326, 2015. https://doi.org/10.3389/fgene.2015.00326 